\title{
Russian university teachers' ideas about pedagogic frailty
}

\author{
Svetlana Nikolaevna Kostromina \\ Daria Sergeevna Gnedykh \\ Ekaterina Aleksandrovna Ruschack
}

Saint-Petersburg State University, Saint-Petersburg, Russian

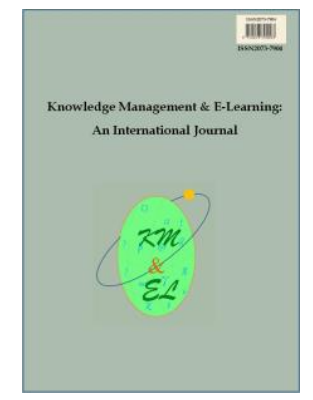

Knowledge Management \& E-Learning: An International Journal (KM\&EL) ISSN 2073-7904

\section{Recommended citation:}

Kostromina, S. N., Gnedykh, D. S., \& Ruschack, E. A. (2017). Russian university teachers' ideas about pedagogic frailty. Knowledge Management \& E-Learning, 9(3), 311-328. 


\title{
Russian university teachers' ideas about pedagogic frailty
}

\section{Svetlana Nikolaevna Kostromina}

Faculty of Psychology

Saint-Petersburg State University, Saint-Petersburg, Russian

E-mail: lanank68@gmail.com

\section{Daria Sergeevna Gnedykh*}

Faculty of Psychology

Saint-Petersburg State University, Saint-Petersburg, Russian

E-mail: d.gnedyh@spbu.ru

\section{Ekaterina Aleksandrovna Ruschack}

Faculty of Psychology

Saint-Petersburg State University, Saint-Petersburg, Russian

E-mail: e.ruschak@spbu.ru

*Corresponding author

\begin{abstract}
The paper focusses on the problem of pedagogic frailty in Higher Education in Russia. The main dimensions of pedagogic frailty are described from the point of view of Russian teachers and researchers. Concept maps were used to reveal the teachers' ideas about the challenges presented by 'pedagogic frailty'. The content analysis of their concept maps revealed interviewees' perceptions of the possible options that can be used to generate solutions to the problems created by pedagogic frailty. The detailed analysis of original solutions and examples observed in the interviewees' concept maps is presented. Based on the results of the research, guidelines about solutions to the problem created by pedagogical frailty are proposed.
\end{abstract}

Keywords: Pedagogic frailty; Research teaching nexus; Pedagogy and discipline; Concept maps

Biographical notes: Svetlana N. Kostromina is the professor of the department of personality psychology at The Saint-Petersburg State University, Doctor of Science in Psychology, the author of more than 140 scientific works in the field of educational psychology, educational neuroscience, processes of selforganization and personal regulation of educational activities. She is the president of the St. Petersburg Psychological Society.

Daria S. Gnedykh is a senior lecturer of the department of psychology of education and pedagogy at The Saint-Petersburg State University, candidate of Science in Psychology. Her research interests focus on psychology of learning activity, cognitive learning processes, psychology of e-learning, neuroscience.

Ekaterina A. Ruschack is the first year graduate student of the department of personality psychology at The Saint-Petersburg State University. Her research interests focus on the psychological mechanisms of e-learning, teaching 
methods of e-learning, e-learning efficiency.

\section{Introduction}

The problem of pedagogic frailty (detailed in Kinchin et al. (2016), and Kinchin and Francis (2017)) is currently important not only abroad but also in Russia. Today Russian University teachers work in conditions of increased demands for training and professional success. Their qualification and relevance is determined by their level of knowledge, their involvement in research activities, their flexibility of usage of different teaching methods, their application of the latest scientific achievements in the development of a training course, and their level of usage of Internet resources and electronic learning technologies in their work. Developing expertise in different areas of professional activity (teaching and research, the orientation in their subject area and level of teachers' training) represents a 'special condition' of professionalism.

The modern system of education requires teachers to adapt quickly to innovations in the pedagogical process, but not all teachers are willing and able to meet these requirements (Elistratova, 2010), and this affects their professional and personal development. Even when teachers have a deep knowledge of the subject, the lack of teacher training often results in inefficient development of educational processes and application of teaching methods that prevents them from obtaining high educational quality results. However, teacher training does not guarantee a high level of teaching proficiency if a teacher is limited by traditional educational processes, and is not involved in scientific research and scientific communication.

The questions which are actively discussed by the Russian scientific community are: how to exploit the benefits of the research teaching nexus; how to develop modern teacher training; and how to increase teachers' acquisition of new educational technologies in a manner that maintains the interest and capacity to carry out scientific research (Makarova, 2006; Shipilina, 2007; Makarova \& Sharshov, 2013; Skoryk, 2013; Tkachyova \& Sazonova, 2014). These challenges are relevant not only for Russia but for the world wide pedagogical science. For instance, in the report Adams Becker et al. (2017) discussed in detail the long-term and short-term trends of technology adoption in higher education and the difficulties associated with it, as well as the teacher's professionalism in his connection with the use of different learning strategies (problembased learning and project-based learning) and implementation of blended learning, collaborative learning, integration of formal and informal learning. However, this educational discourse is fragmented in the absence of the application of the integrative concept that would characterize pedagogic frailty in the Russian language. It seemed for us that searching for a solution to this problem is very important for education development in Russia.

\section{Background}

One of the reasons for the fragmented discourse about the research teaching nexus, subject-specific and didactic training of teachers, resources of their personal and professional development is the lack in the Russian psychology-pedagogical literature of the term "pedagogic frailty". This lack of appropriate terminology prevents a systematic analysis of the factors that cause pedagogic frailty. 
Kinchin (2016, p. 119) writes that, "in the context of higher education, one might observe a concept of pedagogic frailty when hassled colleagues find the cumulative pressures of academia (persistent stressors) eventually inhibit their capacity to change and respond to an evolving teaching environment, leading them to adopt what they consider a 'safe' and sustainable pedagogic approach". A traditional approach to training is considered as basic and stable where there are no innovations and teachers stay at a safe level ignoring something new (Kinchin, 2016; Kinchin \& Francis, 2017).

Kinchin (2016) and Canning (2007) comment on the set of conditions that often occurs due to stress that accompanies changes in the environment of higher education. These states are mediated by a complex set of factors the exact structure of which depends on courses taught and a teacher. At the same time the situation for some teachers can be a problem or a crisis, for others - a challenge and an opportunity.

Drawing on the term "frailty" from medicine (e.g. Clegg \&Young, 2011) draws the attention of the academic community towards some characteristics that contribute to teachers' failure to adequately respond to changes in stressful situations, decrease in adaptive capacity in connection with the loss of "the complexity of the skill adaptation", the fatigue that comes from repeated efforts to adapt to changes, etc. These problems often arise in the educational environment. Karataeva (2013) writes about the teachers' psychological barriers that appear in the implementation of innovations in pedagogical process. She noted that a teacher, being a supporter of the traditional type of teaching, lacking confidence in the success of a new teaching method - creating "anti-innovative" barriers. Volkov (2012) supposes that change the style of interpersonal interaction in University is a necessary condition for the development of professional qualities of a teacher in the modern education system. Starcev and Sharshov (2012) confirm this idea investigating pedagogical conditions that increase efficiency of teacher-student interactions. Requirements to change the style of interaction can be a strong stressor for teachers. Fadeeva and Fedoseyeva (2015) conducted a study of teachers' general state in the profession and in the university, the results of which correlate with the characteristics of pedagogic frailty. Vasyukova and Klimenko (2011), Gredyushko (2009) and Matveeva (2013) write also about the decrease in teachers' enthusiasm, and the increased feeling of fatigue and negativity in relation to their professional activities.

All of the problems and difficulties named above suggest that it is necessary to form a unified view of the teaching in the higher education system which will allow to build a general model that takes into account the dimensions of pedagogic frailty.

Kinchin et al. (2016) identify four main dimensions of pedagogic frailty: regulative discourse, locus of control, pedagogy and discipline and research teaching nexus. Thus, the generalized model of pedagogic frailty describes the relationship between the four key elements (Kinchin \& Winstone, 2017).

The first dimension includes the lack of explicit and shared values that contribute to effective regulative discourse. The regulative discourse (described by Bernstein, 2000) is associated with the values underlying the training but not with the mechanisms of the educational process. Regulative discourse frequent remains unspoken so as the values lie on the basis of teaching at the university because the focus is more tangible actions and results. For instance, improving assessment, compliance with the curriculum, the curriculum content, sequence of teaching disciplines (Kinchin et al., 2016). The accomplishment of these formal requirements can lead to the fact that students' preparedness to assimilate information is under recognized, and methods and techniques that allow students to immerse in a professional environment and to develop professional values are rarely thought. 
The second dimension reveals an inconsistency between the contents of the discipline and didactics underlying teaching. Kinchin et al. (2016) emphasize the importance of the concept of authenticity in pedagogy and discipline. Learning is considered authentic when it gives to students the ability to solve complex problems in the academic or professional environment. Thus, learning gains an importance in the context of their everyday or professional life (Kinchin \& Winstone, 2017). This kind of teaching has a special significance for applied disciplines as it forms the professional identity of students (Kostromina, 2008). There is an emphasis on the specificity of the teaching methods for certain disciplines. For instance, a teacher of acting has doubts whether essay writing regulated by the university will prepare future artists to the stage. In addition, there is the issue of students' preparation for "real life" which is difficult to present in pedagogical situations and hence there is the opposition "competence vs experience". Accordingly, the authenticity can be more determined by high-demand occupations. The connection between authentic learning and teaching is not simple and the authenticity of learning is not always the result of quality teaching.

The third dimension describes the tension arising from competing roles of teacher and researcher (research-teaching nexus). The relation of research and teaching is a sharing of knowledge between these two elements for their mutual strengthening, and supporting students learning. Knowledge in each of these areas has their own specificity which plays different roles depending on the context of the educational process. Despite the significance of the simultaneous implementation of teaching and research activities, teachers usually focus on one or the other. This is especially evident in practice-oriented fields. For example, research as an activity is unknown to many teachers of performing arts engaged in the practice and improvement of professional competencies rather than scientific study (Kinchin et al., 2016).

Finally, the fourth dimension (locus of control) focuses on the interactions between teachers and the decision-making agency of administration that governs training. One of the live system management in higher education could be the system which facilitates workable balance between administration and teacher's autonomy in his professional activity. Such type of autonomy allows teacher to use his life experience in the educational process. Also it is important to strike a balance between the University's image formation, the need to adhere to certain financial indicators. And overall management process should be built considering those values that are inherent in the regulative discourse (Kinchin \& Winstone, 2017).

Each of these dimensions of pedagogic frailty has not only its content but making its own contribution (usually not always equivalent) in the quality of teaching. To solve the pedagogic frailty problem, it is important to understand what factors influence each of these dimensions and how these factors are structured and relate to each other.

Even in the absence of an expression in Russian for "pedagogic frailty", the dimensions of the model and its consequences are actively discussed by the Russian academic community. Shipilina (2007) highlights that the strategy of development of higher education has developed with the entry of Russia into the global community, and the change of socio-economic and political conditions. According to the author these changes require the consideration of methodological problems of education in the new environment. Among a lot of methodological problems Shipilina focusses on management processes. This choice is due to the fact that management is a mechanism for streamlining and harmonization of the educational system which makes possible its development and the transition to a new qualitative state. The following management problems were identified: late decisions of scientific and methodological support, 
ineffective management, lack of regulatory standards, problems of delegation and coordination of educational process. Thus, this issue is correlated with such dimension of pedagogic frailty as locus of control.

Makarova and Sharshov (2013) note that the establishment of a workable balance between research and teaching activities is one of the most important tasks facing universities in developed countries. It is important consider the specifics of the University for formation this balance because a lot will depend on its mission. For example, universities aimed to the development of practical skills (applied orientation) did not initially focus on research activities and a commitment to this balance might be not a priority.

In this aspect the authors point to the problem of assessment of teachers' professional activity. In their opinion it focusses on research and pays less attention to the results of teaching. Thus, the main function of a university - specialist training - becomes less significant. The emphasis on research leads to the fact that, for example, professors and associate professors assign teaching to graduate students. Another outcome of this imbalance is the rejection of research activity and a full engagement in teaching. The complexity and consistency between research and teaching is mostly absent.

Skoryk (2013), Tkachyova and Sazonova (2014) noticed, that over the past few years higher education reforms have been carried out:

a) the frequent modification of educational state standards: 2011, 2013, 2017;

b) the state accreditation with the subsequent correction of identified deficiencies;

c) the innovation on managerial, financial, economic and structural-normative levels;

d) the new personnel policy with the conclusion of "efficient contracts" with a set of requirements to a teacher.

These reforms reduced the interest of teachers to academic activities, increased the desire to stick to the usual teaching methods, and provoked the resistance to change. The intensity of innovation, the lack of explanation of the specific requirements and clarity of what is happening led to the formation of states of apathy, anger, fatigue and anxiety which teachers have (Henderson, Barnett, \& Barrett, 2017; Geryk, 2016). These states correlate with the features of pedagogic frailty described above. It is important to note that despite the intensity of the changes and innovations in Russia the quality of education increases slowly. The reason for this may be the lack of complexity in the study of problems arising when changing the educational process. Such problems include: the role of new technologies in the emergence of the new "university network", the ability of Institutions of higher education to be more flexible in adapting to the needs of society (Bindé, 2005), the international comparability of tertiary education, the ability of tertiary education to disseminate the knowledge it creates (OECD, 2008) (more examples you can see in appropriate sources mentioned above). The exploration of "pedagogic frailty" involves simultaneous consideration of all aspects of this problem.

Certainly, the study of the pedagogic frailty's dimensions should be complex, so we decided to break it down into several stages. In this article we focus on the study of the solutions to the problem of pedagogic frailty within two dimensions: research teaching nexus and pedagogy and discipline. A key element of the analysis is the point of view of Russian university teachers on the solution to the mentioned problems. The purpose of this research is to study the ideas of Russian university teachers about the challenges of pedagogic frailty in the modern education context. 


\section{Research methods}

The research sample was made up of the professors of Saint-Petersburg State University ( $\mathrm{N}=10 ; 5$ men and 5 women) aged 29 to 39 years, average length of service is 10.8 years. The teachers who participated in the study undertake lecturing in psychology, philosophy, social sciences, and history. The following criteria were the basis of selection of participants for the sample:

1. The age and the length of service. Participating in the study teachers had been teaching at least 3 years. In our opinion, working at the University for more than 3 years is sufficient to allow colleagues to "feel" pedagogic frailty through firsthand experience. At the same time teachers are already immersed in the problems of teaching and the process of professional development. Sufficient experience, personal meaning and concern of the teachers in the solution of the problem allowed us to control the participant's motivation (the conscientiousness of the completion) and to consider the received information as received by the expert.

2. The lack of basic pedagogical education. It was important to the teachers acted as "naïve" subjects - they offered exactly their personal vision of solving the problem instead of accepted knowledge from pedagogy or educational psychology on this subject.

Concept mapping was used as a method to study conceptions of the teachers for solving particular problems of pedagogic frailty (in the field of research teaching nexus and pedagogy and discipline) and for the visualization of their expert knowledge.

The method of concept mapping was explained to participants along with the nature of pedagogic frailty and its dimensions during the pre-interview. The participants could ask clarifying questions. Next, they were asked to consider two main issues that determine the appearance of pedagogic frailty: 1) research teaching nexus problem; and 2) pedagogy and discipline problem. Participants were asked to represent their ideas about the solution of these problems summarized as a concept map. After the pre-interview a few days were given to participants for revision of the concept maps. A preliminary list of concepts that can be used in maps was not given. The number of concepts in a map was not limited. Map content, structure and components (concepts and relationships) were analysed by content analysis.

\section{Findings}

20 concept maps were received - 10 maps about the problems solutions connected with the first pedagogic frailty key area, and 10 - with the second (2 maps from each person). Examples of concept maps are presented in Fig. 1, 2, 3, 4 .

The concept map content analysis allowed us to identify the resources that the teachers propose to use to solve outlined problems. The concepts and phrases that were found in the participants' concept maps are presented in Tables 1 and 2. Categories in the tables were identified and named by us on the basis of the content analysis of concept maps. The content of the concepts reflects the specificity of 1) activities of the teacher (which allowed to generalize this and called "teacher agency"), 2) activities of the University administration ("the organizational and administrative resource"), 3) the interaction between a teacher and students ("the resource of the students' joint working 
with a teacher") and 4) the interaction between a teacher and other teachers ("the teacher's resource of joint working with other teachers").

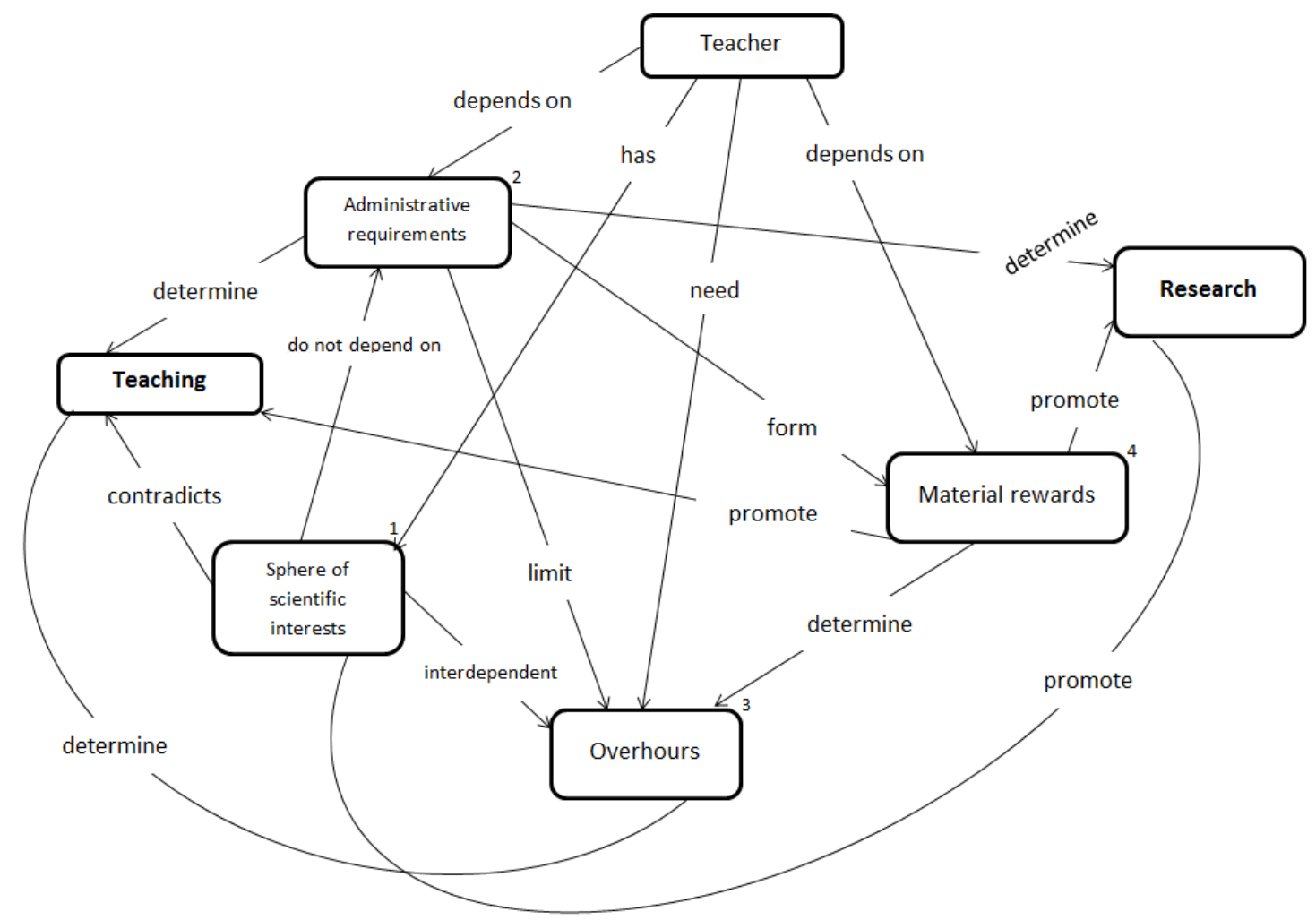

Fig. 1. Concept map showing the problem "Research teaching nexus" solution.

\section{Example No.1}

The exchange of knowledge produced in these two areas of activity of the teacher was recognized as the main way to maintain a balance between teaching and research activities. On the one hand this allows to include the obtained research results in education material. On the other hand - to use experience of teaching activities as foundation for hypothesis testing by research. Overlapping research interests with the taught discipline facilitates the combination of these two activities in academics' work. One of the ways of solving this is the adaptation of courses according to teachers' professional interests: the teacher chooses such course in a curriculum for lecturing which coincide with his/her research interests. Unfortunately, in the real educational process in Russia the distribution of teaching among teachers often occurs with little reference to their wishes. If the content of the courses which are included in the academic load of a teacher is far from the field of his/her research interests $\mathrm{s} /$ he might pay less attention to it and teach without enthusiasm. Such prioritizing will eventually require a greater time commitment and teacher's intellectual resources in research activity that disturbs the balance between research and teaching. Providing opportunities for teachers to participate in the formation of the list of subjects that they intend to teach can increase their satisfaction and consequently to reduce the probability of inducing pedagogic frailty. In this approach organizational and administrative structures play an important role from which the construction of the curriculum depends. A well-constructed curriculum which 
takes into account the teachers' research interests makes it more likely that teaching and research will be integrated in the pedagogical process. Thus, there is an important interaction of "teacher agency" with the organizational and administrative structures (see in Fig.1 concept № 1, Fig.2 concept № 1, 16, 17.

Table 1

The solution of problem "Research teaching nexus"

\begin{tabular}{ll}
\hline Categories & Problem Solution Directions \\
\hline Teacher agency & Overhours; independence from the sphere of scientific interests \\
from administrative requirements; material rewards; ideas; \\
hypothesis; new material; new scientific experience; research \\
activities provide new results which are included in the lecture; \\
teaching activities is the basis for building hypotheses and \\
objectives for research activities; the choice of the general subject \\
of the teaching and research activities; joint research activities with \\
colleagues; to learn writing scientific texts; to gain experience in \\
internships, conferences and workshops and apply it for the \\
organization of teaching and research activities; to use experience \\
which include the results of the research for developing new \\
training materials; the desire to share research results with others; \\
the desire to be appreciated and to receive recognition. \\
Administrative requirements; the correlation of the scientific work \\
results with publications; a well-constructed curriculum; the \\
activity changing from the teaching to researching every 2-3 years; \\
adaptation of courses according to teachers' professional interests; \\
research funding; organization of additional training for teachers \\
which will lead to usage and creation of new methods in the \\
research activities. \\
The scientific work with students; the co-authorship publications \\
The resource of the students
\end{tabular}

On the other hand, if the teacher focuses more on teaching, research funding can increase interest in research activity. Teachers' avoidance of research activity in favour of teaching may be due to the contradiction between the high requirements of the description and formal introduction of research results in published articles and simultaneous poor development of teachers' academic writing skills. Therefore, teachers pay a lot of attention to additional training which promotes not only the usage and creation of new methods in research activities but also develops academic writing skills. Gained teaching experience during the internship can also be applied to organization studies (see in Fig. 1 concept № 4, Fig. 2 concept № 2, 3, 4, 5, 6, 7, 14, 15).

Another important resource is personal motivation and ambitions of teachers - the desire to learn, to share research results with others, the desire to be appreciated and to receive recognition. This resource might be not always relevant because it is impossible to assert that all teachers love to teach (including teachers in Russia). Many of them prefer research activity (see Table 1). The following solution to this problem suggested by one of the participants seems to us to be quite original. It is the activity changing from the teaching to researching every 2-3 years (see Table 1). The idea is that for two years the teacher is engaged only in research but the next two years - only is engaged in 
teaching. Thus, there is full concentration on only one activity without being torn between them which leads to improve its quality and reduce the anxiety level of the teacher. The proposed solution allows in general to eliminate the problem teachingresearch nexus, but does not eliminate the contradictions that arise in teachers in the process of combining of these two activities.

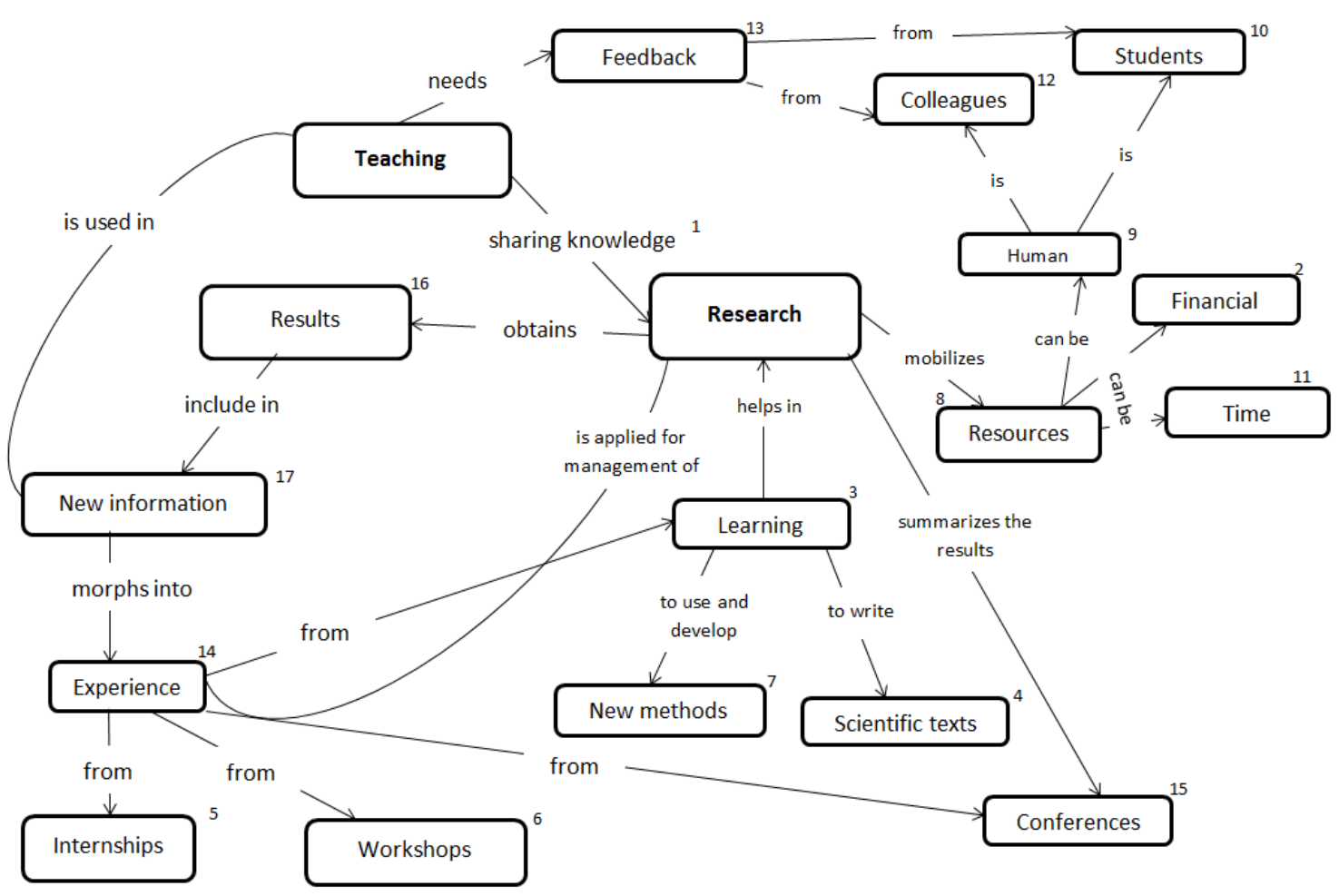

Fig. 2. Concept map showing the problem "Research teaching nexus" solution.

Example No. 2

The organization of teachers' joint research work with students and co-authored publications can help in the development of teachers' research activities. Obviously, it is possible when the teacher manages to combine teaching and research activity. The inclusion of students in research will allow a teacher to not spend on research activities all his overhours doing research alone and to devote it for preparation for the lectures and practical classes (see in Fig. 2 concept № 8, 9, 10).

Another issue that was noted by teachers is the raising the various demands to him by the University administration. Teachers included in the documentation procedure, received administrative orders that take them a long time. In accordance with that the time devoted to teaching (preparation for classes) or research reduces and difficulties in keeping the balance between research and pedagogical practice arise. Administration must allot clear tasks to the teachers. The tasks should have unambiguous interpretation because unclear tasks may require the teacher to spend time on understanding what is required of him (see in Fig. 1 concept № 2, 3, Fig. 2 concept № 11).

Thus, the solution of the problem of research teaching nexus requires an integrated approach that involves close collaboration between teaching staff (taking into 
account the interests, motivation and other personal resources of teachers) and the administration of universities (see in Fig. 2 concept № 12,13). Solutions in Fig. 1 and Fig. 2, given as examples, do not contradict but complement each other. Figure 1 in general presents solutions that reflect the relationships between categories "teacher agency" and "the organizational and administrative resource". Fig. 2 in more detail describes not only the resources that could be used by the teacher and the administration of the University, but others ("the resource of the students' joint working with a teacher") which are necessary for the solution of problems arising from the emergence of the imbalance between research and teaching activities.

Possible solutions of the problems which related "Pedagogy and discipline" are presented in Table. 2. Content analysis of the concept maps revealed that teachers assign a significant role both its own activity and activity of the University administration, as well as cooperation with students. This allowed us to name categories the same as in table 1 , although their content is not the same as was presented in the description of the solutions of research-teaching nexus problem. Furthermore, unlike the solutions to the first discussed problem, there is the fourth category - "the resource of the students' joint working with a teacher" which can indicate in teachers' ideas the presence of more opportunities to solve the problem "Pedagogy and discipline" compared to the teachingresearch nexus (Table. 2).

Table 2

The solution of problem "Pedagogy and discipline"

\begin{tabular}{ll}
\hline Categories & Problem Solution Directions \\
\hline Teacher agency & $\begin{array}{l}\text { The usage of the pedagogical experience; interest to the } \\
\text { discipline; training of the skills of public speaking; the study of } \\
\text { information technologies and innovative teaching methods; } \\
\text { knowledge of psychology of mental processes; application of } \\
\text { modern scientific knowledge, new pedagogical developments and } \\
\text { ways of teaching; self-confidence; motivation; a plan for adoption } \\
\text { of a new method of teaching into educational process. }\end{array}$ \\
$\begin{array}{ll}\text { The organizational and } \\
\text { administrative resource }\end{array}$ & $\begin{array}{l}\text { Curriculum; upgrade training course for teachers; visit courses on } \\
\text { pedagogy which are taught on PhD programs; lectures for } \\
\text { different audiences; the Institutional recognition of teachers. }\end{array}$ \\
$\begin{array}{l}\text { The resource of teacher's joint } \\
\text { vorking with other teachers }\end{array}$ & $\begin{array}{l}\text { Visiting lectures of colleagues and foreign lecturers; the } \\
\text { acquaintance with experience of school-teachers. }\end{array}$ \\
$\begin{array}{l}\text { The resource of the students } \\
\text { joint working with a teacher }\end{array}$ & $\begin{array}{l}\text { Feedback; the forming of all kinds of knowledge. } \\
\end{array}$
\end{tabular}

Within the "teacher agency" category there are elements that provide a confidence in the application of innovative teaching methods, motivation of learning new technologies, interest to teaching disciplines. And also those actions that require teacher's engagement and activity: skills training, the study and application of new pedagogical developments and ways of applying knowledge. Thus, the teachers believe that desire and activity of the teachers to expand their knowledge and experience play a big role in the solution of the problem of the relation between knowledge of pedagogy and teaching methodology of various disciplines (pedagogy and discipline) (see in Fig. 3 concept № 1, 4, Fig. 4 concept № 1, 2, 3, 4). 
The increasing of pedagogical competence includes not only the acquirement of pedagogical technologies but also extension of knowledge in the field of psychology especially knowledge about the patterns of mental activity of students in learning. This knowledge will help teachers to make informed and correct choices about teaching methods for the academic field in which he is an expert and these methods should be appropriate to the audience (see Table 2).

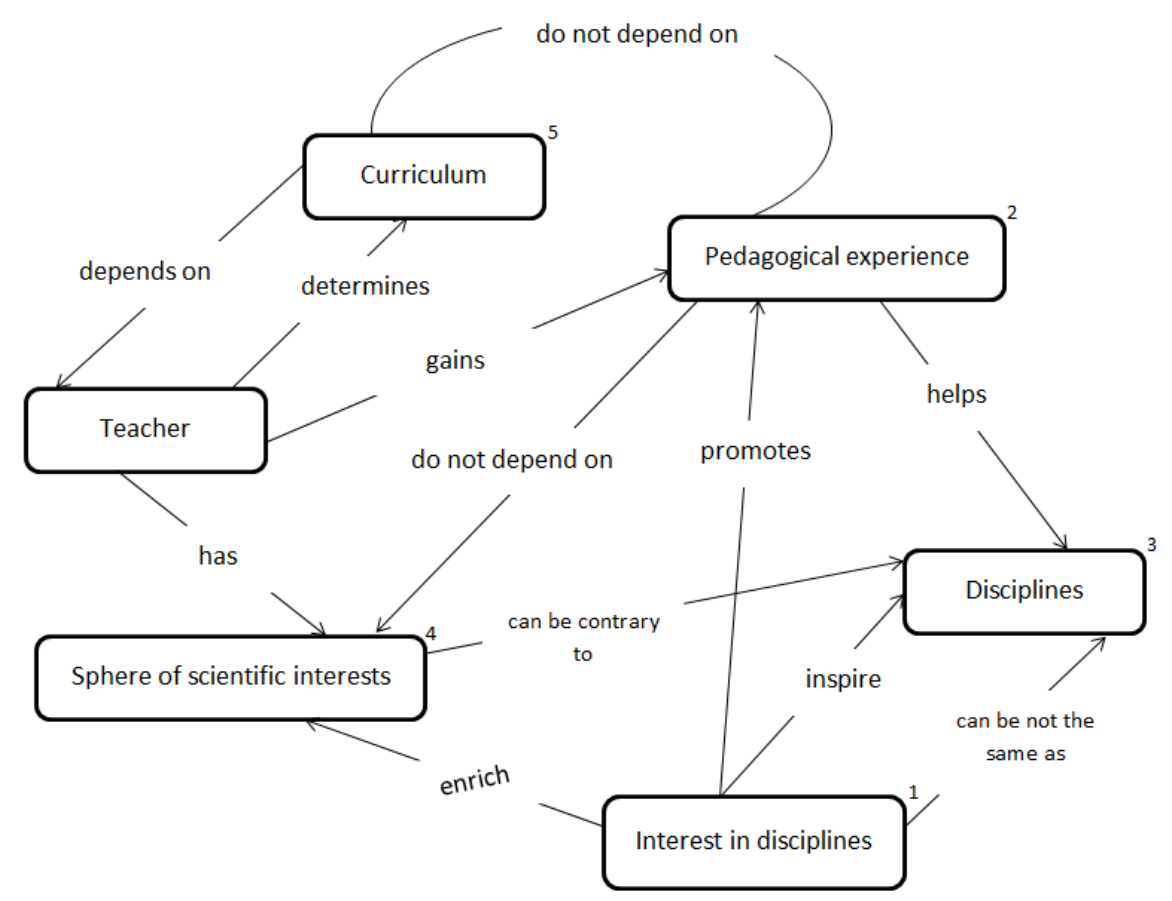

Fig. 3. Concept map showing the problem "Pedagogy and discipline" solution.

$$
\text { Example No. } 1
$$

The selection of teaching methods should be based on the course content and its objectives. However, the teacher is not always able to keep up to date with changes in pedagogical techniques. Thus, a teacher must work systematically to develop their understanding in this area, requiring additional effort and time allocation (see Fig. 3 concept № 2, 3, 5).

Generation of plan for adoption of a new teaching method by a teacher for his subjects can increase the probability of improved learning outcomes. However, it also requires a greater attention and understanding the impact of certain method on the efficiency of knowledge acquisition by students. On the one hand, if a teacher has a clear plan for application of pedagogical innovations in teaching, it will allow him to reduce the uncertainty of the situation and get going. On the other hand, a teacher often has no time to do this kind of elaboration because of commitment of work. In this regard, he teaches based on the usual and proven methods not paying attention to the fact that they may not entirely contribute to students' knowledge acquisition (see Table 2).

Another way to solve the problem of pedagogy and discipline offered by the teachers is attending upgrade training course or $\mathrm{PhD}$ programs on pedagogy to improve pedagogical skills. Such courses, according to teachers, should be organized by the 
administration of the University. In Russia postgraduate study involves the pedagogical interning that can help future teachers to develop their own model of teaching and form their own understanding of how to do the educational process in the high education. Retired teachers might consult as invited experts or consultants that help graduate students in their development as teachers, which enhances their psychological readiness for their future teaching (see Fig. 4 concept № 3, 5).

In addition, it is necessary to implement Institutional recognition (prize) to teachers for application of innovative and information teaching technologies. This will increase the motivation of teachers to master new teaching methods and to associate them with subject area of disciplines. However, it is necessary to consider that the motivation is certainly important but is not sufficient for building an optimal educational process. Ongoing support of teachers is reasonably required in order to cope with the newly emerging and new challenges, and, of course, the exchange of experience in such a situation plays an important role (see Table 2).

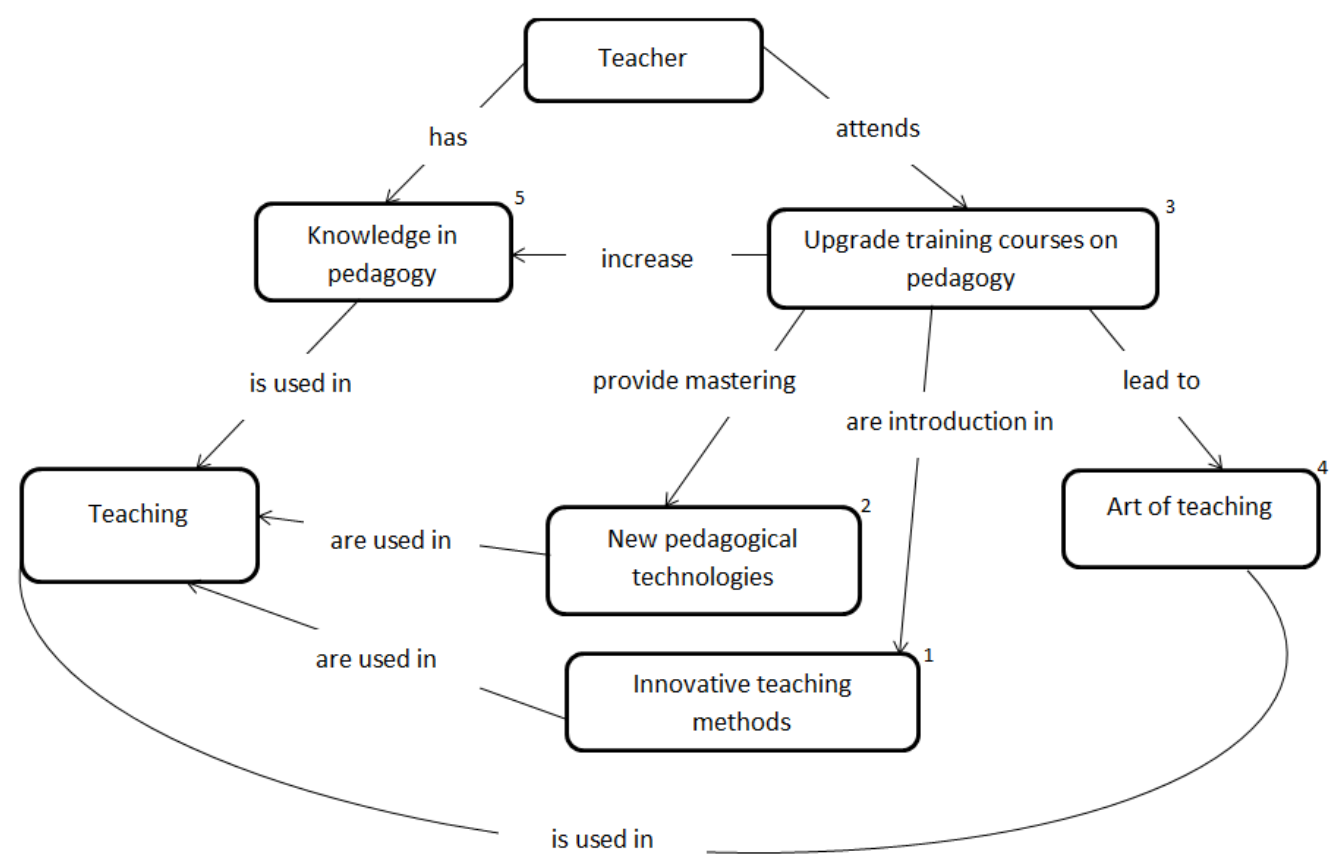

Fig.4. Concept map showing the problem "Pedagogy and discipline" solution.

Example No. 2

To reduce the lack of flexibility of the university system it is also important to consider the administrative structures. Assimilation of innovative pedagogical technologies into educational process is long and time-consuming and requires a lot of approvals at various levels of management. Thus, the university quality assurance system hinders the teachers' rapid adoption of innovative teaching methods which could improve the quality of student learning outcomes.

Encouraging teachers to lecture for different audiences (not only for students but for adults, professionals of different areas) seemed to be an interesting solution to the 
problem. One of the basic rules of pedagogy is that depending on the specifics of audience the same content of a discipline should be taught differently. Accordingly, this requires teachers to acquire a broad set of teaching techniques. Such encouragement will help the teacher to master more and more pedagogical techniques which will ultimately strengthen the relationship between pedagogy and disciplines (see Table 2).

Based on the concept maps of teachers in this study we identified the category of "teacher's joint working with other teachers". Attending lectures of national and foreign lecturers will help to increase the diversity of teaching methods avail to their colleagues, and to see them being used in the authentic classroom situations. Such cooperation is offered not only in universities but also in schools. The adoption of innovative teaching is often adopted first in schools before it is later adopted by university teachers. In Russia the reforms in education often begin with school education and only after affect higher education. Second, many teaching methods that are applied to pupils are also suitable for students. Thus, the concept maps of teachers suggest that visiting school classrooms (teaching a subject related to the teacher's discipline) can give lecturer additional knowledge in the field of pedagogy and be an incentive for him/her to use this knowledge in the learning process (see Table 2).

To develop strategies of improving the application of pedagogical achievements in teaching practice the resources of students are supposed to be used. Gathering feedback from students about the quality of teaching methods, opportunities for the formation of students' knowledge helps us to look at the problem from the perspective of those who directly feel the impact of pedagogical interventions. For example, a negative evaluation can let a teacher to realize the necessity of change in teaching methods.

Basing on the analysis of concept maps we can conclude that all of the resources required to solve the problem of "pedagogy and discipline" might be a good foundation for creating conditions that reduce the probability of professional and emotional apathy, fatigue and anxiety among teachers.

\section{Discussion and conclusions}

The significance of this study is in participating of teachers from different subject areas, which are directly involved in the educational process. This allowed us to look deeply at teaching problem and to analyse proposed solutions from the position of the subjects with practical experience in the situation of pedagogic frailty. A comparative analysis of the proposed solutions according to the teachers' subject areas was not the objective of the study. The reason is that, in our opinion, the sample is insufficient for this comparison. But it is certainly an interesting direction for further research.

The ways to reduce the likelihood of pedagogic frailty proposed by teachers are consistent with those of other researches. Kharlamova (2013) pays attention to the fact that the teaching of the liberal arts should go in line with the profile of a university. This gives the opportunity to illustrate the sections of the liberal arts by the specific material of the respective special sciences. Thus, the conjunction of knowledge about pedagogy and discipline is traced and enhanced. Solovova (2013) indicates that the development of complex training programs can be attributed to the promising directions of development university's teaching methods. The teachers who participated in our study are agreed with that (see Fig. 4). She also noted that the teacher's advisable to consider the specifics of the training on liberal arts, natural-scientific, technical faculties in a design of lessons, in particular, foreign languages. This requires from the teacher an application of the most 
useful forms of representation of content of one's subject area, powerful examples, illustrations, demonstrations that make it more comprehensible to students. In this way Shulman determined pedagogical content knowledge - those that help teacher to teach efficiency based on "an understanding of what makes the learning of specific topics easy or difficult” (Shulman,1986, p. 9).

Solovova (2013), Vorob'yova, Plekhanova, and Kil'dyushkina (2014) aptly note that state standards (FSES) of higher education in Russia are focused on the necessity of students' academic autonomy improvement by suggesting the interactive nature of the lessons. Thus, for teachers to satisfy this condition, they are required to move away from the traditional teaching methods and to turn towards more student-centred approaches The perceptions of the requirement to master new educational technologies and innovative teaching methods were illustrated by the teachers in the concept maps (see Fig. 4).

Kazachihina (2012) draws attention to the necessity of improvement of future teachers' psychological readiness to innovative activity. The author named the fear of discovery of teachers' own incompetence and personal failure, concern about self-worth as internal teachers' reasons related to the resistance of new in their professional activities. From the analysed concept maps we can see that teachers pointed out that a teacher's self-confidence and motivation are necessary for the solution of the problem of implementing knowledge from the field of pedagogy in the teaching of various disciplines (see Table. 2). But if the majority of teachers in their maps mentioned only upgrade training courses or internship, Kazachihina considers the personal growth training as the most effective method of adjustment teachers for innovative activity. As a result, this training leads to qualitative changes of teacher's personal potential providing a variety of professional perspective, the ability to the destruction of stereotypes and to the formation of new innovation attitudes. Similar questions were discussed by Johnson, Pas, Loh, Debnam, and Bradshaw (2017). Also questions about collaborative work and demands of usage innovative methods of learning management are discussed by BaleghiZadeh, Ayub, Mahmud, and Daud (2017), Budiardjo, Pamenan, Hidayanto, Meyliana, and Cofriyanti (2017) and Hao, Barnes, Branch, and Wright (2017).

It is important that the teachers realize the role of working collaboratively with colleagues (mutual observation of lectures and seminars) to improve their teaching skills (see Table. 2). The effectiveness of this interaction was demonstrated in the course of the Tempus-Tasis - a European project for professional development in which emphasis was placed on the organization of experience exchange of the participants of the course (Viktorenkova, 2009). Unfortunately, as noted by some authors, this type of activity is not sufficiently developed in Russia.

The analysis of professional activity of teacher of the university held by Smirnov (2005) revealed that the research function in conjunction with the educational function is specific only for $20 \%$ of teachers. At the same time, many authors note that the alliance of teacher's achievements of pedagogical and research activity makes possible the formation of his position and students' acceptance him as professional and personality (Magomedova, 2012; Efendiev \& Reshetnikova, 2007). According to the students' opinion, teacher's research work increases his academic knowledge and develops creative potential of a teacher (Makarova \& Sharshov, 2013).

The majority of teachers who participated in our research pointed out that cash rewards can provide the incentive to engage in research work. However, Roshchina and Yudkevich (2009) cast doubt on the effectiveness of this relationship. They noted a 
negative relationship between teachers' attitudes towards research and teaching and administration.

The students' collaborative working with a teacher has been identified as one of the resources increasing the significance of research activities (see Table. 1). Churakova (2006) considers the teacher's research activity as a condition of improving professional competence. She believes that this is a necessary component for professional development of teachers.

In line with our findings we propose recommendations, which can be used for solving discussed problems of pedagogic frailty (research teaching nexus \& pedagogy and discipline) in two ways:

I. To create a balance between elements of the research teaching nexus, university teachers need to proceed as follows:

- $\quad$ The usage by teacher knowledge received in the course of research in teaching (integrated in the content of lectures and practical classes). Teaching experience might be the basis for research activities for cases when it possible.

- Offer teachers some choice in the subjects that they going to teach. This increases the probability of a correlation between course content and teachers' research interests.

- Increase interest in research activity through increased availability of funding.

- Enhance teachers' skills for academic writing.

- $\quad$ Provide a programme of training in the use of new methods in research activities and internships to gain wider teaching experience.

- Alternate between teaching and research activities every 2-3 years.

- Organization of collaborative research between teachers and students - including co-authoring publications.

II. To solve the problem of pedagogy and discipline is needed to:

- Increase teachers' confidence in applying innovative teaching methods, motivation to development of new technologies.

- Encourage the study and application of new educational developments and ways of presenting knowledge.

- Introducing elements of educational psychology, the teachers so they can better appreciate students' mental processes in learning activities.

- $\quad$ Organize research in the field of pedagogy, as well as encouraging engagement with the scholarship of teaching to support practice.

- Generation by the teacher of a deliberate action plan to incorporate new teaching methods for their subjects.

- Engage in teacher development courses or courses on pedagogy which are taught on $\mathrm{PhD}$ programs.

- Encourage teachers to lecture to various audiences - students, adults, professionals, etc.

- Visiting lectures of colleagues and foreign lecturers, school-teachers to get acquainted with the experience of applying different pedagogical techniques in the educational process. 
- Regularly collecting evaluative feedback from students about the quality of the teaching methods.

Finally, further research on this topic should be continued with a view to the formation of a coherent complex of administrative, psychological and pedagogical measures to create conditions that mitigate the negative consequences of pedagogic frailty, or prevent its occurrence.

\section{References}

Adams Becker, S., Cummins, M., Davis, A., Freeman, A., Giesinger, H. C., \& Ananthanarayanan, V. (2017). NMC horizon report: 2017 higher education edition. Austin, Texas: The New Media Consortium.

Baleghi-Zadeh, S., Ayub, A. F. M., Mahmud, R., \& Daud, S. M. (2017). The influence of system interactivity and technical support on learning management system utilization. Knowledge Management \& E-Learning, 9(1), 50-68.

Bernstein, B. (2000). Pedagogy, symbolic control and identity. Lanham, MD: Rowman \& Littlefield.

Bindé, J. (2005). The future of higher education. In J. Bindé (Ed.), Towards Knowledge Societies (pp. 87-98). Paris: Unesco.

Budiardjo, E. K., Pamenan, G., Hidayanto, A. N., Meyliana, \& Cofriyanti, E. (2017). The impact of knowledge management system quality on the usage continuity and recommendation intention. Knowledge Management \& E-Learning, 9(2), 200-224.

Canning, J. (2007). Pedagogy as a discipline: Emergence, sustainability and professionalisation. Teaching in Higher Education, 12(3), 393-403.

Churakova, M. V. (2006). Teacher's research activity as a condition of professional competence improvement. Vestnik YUzhno-Ural'skogo gosudarstvennogo universiteta. Seriya: Social'no-gumanitarnye nauki, 17(72), 270-273.

Clegg, A., \& Young, J. (2011). The frailty syndrome. Clinical Medicine, 11(1), 72-75.

Efendiev, A. G., Reshetnikova, K. V. (2008). Teachers' professional activity in Russian universities: Problems and main trends. Voprosy obrazovaniya, 1, 87-119.

Elistratova, N. N. (2010). The modern problems of informatization of higher education. Vestnik Ryazanskogo gosudarstvennogo universiteta im. S.A. Esenina, 29. Retrieved from https://cyberleninka.ru/article/v/sovremennye-problemy-informatizatsiivysshego-obrazovaniya

Fadeeva, I. M., \& Fedoseeva, M. V. (2015). The subjective well-being of university teacher in society, in profession and in university. Monitoring obshchestvennogo mneniya: ehkonomicheskie i social'nye peremeny, 6(130), 153-163.

Geryk, M. (2017). Global challenges for the universities and managers of the higher education sector. In Proceedings of the AHFE 2016 International Conference on Human Factors, Business Management and Society (pp. 455-464).

Gredyushko, O. P. (2009). Emotional "Burning-out" of teachers of higher educational establishments. Filologiya i kul'tura, 2-3, 17-18.

Hao, Q., Barnes, B., Branch, R. M., \& Wright, E. (2017). Predicting computer science students' online help-seeking tendencies. Knowledge Management \& E-Learning, 9(1), $19-32$.

Henderson, M., Barnett, R. B., \& Barrett, H. (2017). New developments in transnational education and the challenges for higher education professional staff. Perspectives: Policy and Practice in Higher Education, 21(1), 11-19.

Johnson, S. R., Pas, E. T., Loh, D., Debnam, K. J., \& Bradshaw, C. P. (2017). High school teachers' openness to adopting new practices: The role of personal resources 
and organizational climate. School Mental Health, 9(1), 16-27.

Karataeva, N. G. (2013). The teachers' psychological barriers to pedagogical innovations. Vestnik Voronezhskogo gosudarstvennogo tekhnicheskogo universiteta, 9(3-2). Retrieved from https://cyberleninka.ru/article/v/psihologicheskie-barieryprepodavateley-na-puti-pedagogicheskih-innovatsiy

Kazachihina, M. V. (2012). Development set on innovation in teacher. Innovacionnye proekty i programmy $v$ obrazovanii, 4, 0-35.

Kharlamova, T. I. (2013). Teaching of humane subjects based on the profile of a university. Izvestiya MGTU “MAMI”, 1(15)-6, 195-202.

Kinchin, I. M. (2016). Visualising powerful knowledge to develop the expert student: A knowledge structures perspective on teaching and learning at university. Rotterdam: Sense Publishers.

Kinchin, I. M., Alpay, E., Curtis, K., Franklin, J., Rivers, C., \& Winstone, N. E. (2016). Charting the elements of pedagogic frailty. Educational Research, 58(1), 1-23.

Kinchin, I. M., \& Francis, R. A. (2017). Mapping pedagogic frailty in geography education: A framed autoethnographic case study. Journal of Geography in Higher Education, 41(1), 56-74.

Kinchin, I. M., \& Winstone, N. E. (Eds.). (2017). Pedagogic frailty and resilience in the university. Rotterdam: Sense Publishers.

Kostromina, S. N. (2008). The psychological basics of professional formation during the studies at university. Vestnik Sankt-Peterburgskogo universiteta. Seriya 12. Psihologiya. Sociologiya. Pedagogika, 4, 329-340.

Magomedova, R. M. (2012). Teacher's problem areas in the modern university. Kazanskij pedagogicheskij zhurnal, 94(4). Retrieved from https://cyberleninka.ru/article/v/problemnye-oblasti-v-deyatelnosti-prepodavatelyasovremennogo-vuza

Makarova, L. N. (2006). Factors that stipulate research activities as a necessary condition of the efficiency of university teacher individual style development the professional burnout of high school teachers. Gaudeamus, 9(1), 106-118.

Makarova, L. N., \& Sharshov, I. A. (2013). Scientific and pedagogical activity of future of higher education institution teacher: problem of ratio. Social'no-ehkonomicheskie yavleniya i processy, 53(7), 197-203.

Matveeva, T. N. (2013). The problem of professional burnout of teachers of higher educational institutions. Perspektivy nauki i obrazovaniya, 6, 124-127.

OECD. (2008). Tertiary education for the knowledge society - OECD thematic review of tertiary education: Synthesis report. Retrieved from https://www.oecd.org/education/skills-beyond-school/40345176.pdf

Roshchina, Y. A. M., \& Yudkevich, M. M. (2009). Factors of research activity of university professors: Administration's policy, contract incompleteness or environment influence? Voprosy obrazovaniya, 3, 203-228.

Shipilina, L. A. (2007). The problems of development of higher professional education in modern conditions: administrative and methodological aspects. Psihopedagogika $v$ pravoohranitel'nyh organah, 29(2), 64-68.

Shulman, L. S. (1986). Those who understand: Knowledge growth in teaching. Educational Researcher, 15(2), 4-14.

Skoryk, Y. M. (2013). Factors that stipulate the professional burnout of high school teachers. Vektor nauki TGU. Seriya: Pedagogika, psihologiya, 4, 184-187.

Smirnov, S. D. (2005). Pedagogy and psychology of higher education: From activity to personality. Moskva.: Akademiya.

Solovova, E. N. (2013). New tendencies in teaching foreign languages at tertiary level. Vestnik MGIMO Universiteta, 33(6), 67-70. 
Starcev, M. V., \& Sharshov, I.A. (2012). Pedagogical conditions of increase of efficiency of interaction of teachers and students of higher education institution. Social'noehkonomicheskie yavleniya i processy, 11, 350-354.

Tkachyova, T. M., \& Sazonova, Z. S. (2014). Emotional burnout teacher: Prevention and elimination of the consequences. Vestnik FGOU VPO MGAU, 4, 30-35.

Vasyukova, A. N., \& Klimenko, L. V. (2011). The emotional burnout syndrome in the teacher's professional activity. Psihologiya $i$ pedagogika: metodika $i$ problemy prakticheskogo primeneniya, 18, 147-151.

Viktorenkova, S. V. (2009). Organization of joint activity of university teachers: Problems and prospects. Vestnik Tomskogo gosudarstvennogo pedagogicheskogo universiteta, 2, 27-30.

Volkov, N. G. (2012). Teacher's personality and new technologies of education in the innovative university. Vestnik Kazanskogo tekhnologicheskogo universiteta, 15(10), 392-399.

Vorob'yova, E. G., Plekhanova, E. A., \& Kil'dyushkina, I. G. (2014). Innovative approach in teaching of economic disciplines in universities: technology and methods of training. Izvestia vysshih uchebnyh zavedenij. Povolzhskij region. Gumanitarnye nauki, 31(3), 219-233. 